\title{
Effect of pre-harvest salicylic acid treatments on the quality and shelf life of the 'Cresthaven' peach cultivar
}

\author{
Deniz Erogul*, İsmail Özsoydan
}

Department of Horticulture, Faculty of Agriculture, Ege University, 35100 Bornova, Izmir, Turkey

\begin{abstract}
A good peach fruit should have properties of high quality, as these properties directly affect the shelf life. This study aims to determine the effects of different salicylic acid (SA) treatments in the pre-harvest period on the 'Cresthaven' peach cultivar on the fruit quality at harvest and after storage at $2^{\circ} \mathrm{C}\left(8\right.$ days) plus shelf life at $20^{\circ} \mathrm{C}(2$ days). Fruits with SA treatments have better characteristics such as fruit weight, fruit flesh firmness, total antioxidant content, total phenol content and titratable acidity level at harvest and after storage plus shelf life. With treatments, no changes were observed in the total soluble solids both at harvest and after storage plus shelf life. SA treatments decreased loss of fruit flesh firmness and loss of acidity after shelf life, compared with the control. In fruits with $2 \mathrm{mM}$ SA acid treatment, the reduction in fruit firmness and acidity loss were the least, and as a result of the study it was determined as the most effective pre-harvest SA concentration that could be used in the 'Cresthaven' peach variety.
\end{abstract}

Keywords: antioxidant activity, fruit quality, phenol content, Prunus persica Lindl., salicylic acid, storage

\section{INTRODUCTION}

Salicylic acid (SA; ortho-hydroxybenzoic acid) is a natural plant phenolic that regulates plant growth and development processes. SA, whose chemical formula is $\mathrm{C}_{6} \mathrm{H}_{4}(\mathrm{OH}) \mathrm{CO}_{2} \mathrm{H}$, regulates processes, such as heat generation in plants, disease resistance, seed germination, gender polarisation and ethylene production (Srivastava and Dwivedi, 2000; Ding and Wang, 2003; Zhang et al., 2003). In plants that tolerate stress factors, either an increase in the amount of SA synthesis has been observed, or stress tolerance mechanisms that are activated by increasing the concentration of SA in the plant through external treatments have been determined (Ding et al., 2001; Hayat et al., 2010). SA plays a significant role in maintaining equilibrium in redox reactions in plant cell membranes, thus eliminating the effect of reactive oxygen resulting from oxidative stress, by increasing antioxidant enzyme activity (Yang et al., 2004; Wang et al., 2006). SA that provides resistance against pathogen attacks by enabling the genes related to the defence mechanism to be active prevents the biosynthesis and activity of ethylene and abscisic acid during the ripening process of the fruit and thus delays the ripening of the fruit (Baxber et al., 2001; Lu et al., 2011). SA is not a hormone, but it was linked to the activity of ethylene (Zhang et al., 2003).

It is observed that SA has a protective effect during the treatment of strawberries and melons after harvest (Huang et al., 2000; Babalar et al., 2007). It has been reported that SA applied at the end of harvest in pomegranate fruits reduces the harm caused by cold (Sayyari et al., 2009). In peach, it increases the tolerance against cold by inducing a plant defence against biotic and abiotic stress through performance of some treatments before the harvest (Wang et al., 2006). It has been determined that SA treatments made in strawberry, kiwi and bananas protect the fruit quality by preventing ethylene production (Srivastava and Dwivedi, 2000; Xu et al., 2000; Zhang et al., 2003; Babalar et al., 2007). 
Peaches have a very long production season with various varieties harvested in the middle and late seasons and are included in the fruit species that have significant economic returns in the Aegean region of Turkey. Peaches are grown extensively in the Aegean region, mainly the 'Cresthaven', 'Dixired', 'Glohaven', 'Red Globe', 'Elegant Lady', 'Spring Lady', 'Vistarich' and 'Royal Gem' cultivars are cultivated. The long life after the harvest depends on the good quality of the harvested fruits. The treatment performed before the harvest is important for maintaining the quality of the fruit during the period from the harvest to the time the peach reaches the consumer. Therefore, in this study, it was aimed to determine the effects of different doses of pre-harvest SA applications on fruit quality at harvest and post-harvest shelf life in peach.

\section{MATERIALS AND METHODS}

\section{Plant materials}

In this study, the 'Cresthaven' peach cultivar was grafted on 8-year-old GF677 rootstocks in Davutlar (Aydin Province, Turkey). The peach trees were planted within ranges of $5 \times 5 \mathrm{~m}$ and established in the Open Vase (Goble) Training System. Routine cultural practices, such as drip fertigation, hand thinning and summer pruning, were performed in the orchard.

\section{Chemical material}

Sigma Aldrich (Germany) brand SA $\left(\mathrm{C}_{7} \mathrm{H}_{6} \mathrm{O}_{3}\right.$, ACS reagent, ${ }^{3} 99.0 \%$ ) was used as the chemical material.

\section{Methods}

Two different concentrations of SA, 1 and $2 \mathrm{mM}$, were administered at two different times prior to harvest. Different SA concentrations were prepared by dissolving them in a small amount of ethanol and bringing the final volume of SA to $25 \mathrm{~L}$ with water and then applied on the fruit trees. In all treatments, spreading adhesive $(0.04 \%$ Nu-Film-17 ${ }^{\circledR}$, Miller Chemical \& Fertilizer, LLC., Pennsylvania, USA) was added to the solution used. The treatments were performed as two different applications during the evening of the 23rd day and on the 15th day before the harvest. Harvest was conducted on 30 July 2018. The study was established with four replications according to the randomised block design. Every three peach trees was considered a replication. Approximately $4 \mathrm{~kg}$ of fruit were harvested from each tree. The peach fruits were harvested at the time of commercial ripening and brought to the laboratory. The fruits were analysed after harvesting. They were kept in cold storage for 8 days at $2{ }^{\circ} \mathrm{C}$ and $85 \%-90 \%$ relative humidity. Following this, the fruits were moved to room temperature at $20^{\circ} \mathrm{C}$ for 2 days (simulating shelf life). Physical and high-quality analyses were carried out after shelf life.

\section{Physical analyses}

Twenty-five fruits harvested from each replication were weighed on sensitive scales with the accuracy of $0.05 \mathrm{~g}$, and the average fruit weight $(\mathrm{g})$ was found. The fruit width was measured, with a digital compass sensitive to $0.01 \mathrm{~mm}$, from the widest part of the fruit in its equator area. Fruit length was measured with a digital compass, sensitive to $0.01 \mathrm{~mm}$, from the longest part between the stem pits and flower pits of the fruit.

\section{Quality analyses}

Fruit flesh firmness was measured by dipping the $7.9 \mathrm{~mm}$ diameter tip of a texture metre device to a depth of $10 \mathrm{~mm}$ at a speed of $10 \mathrm{~cm} \cdot \mathrm{min}^{-1}$ (Fruit Texture Analyzer, GS-15, GÜSS Manufacturing Ltd., South Africa) around the equatorial plane. The results were expressed as newton $(\mathrm{N})$ force.

Fruit skin and flesh colour were measured in CIE $L^{*}, a^{*}, b^{*}$ by using the Minolta colorimeter (CR-400, Minolta Co., Japan) on both sides of the equatorial region of the peach fruits.

Total soluble solid (TSS) content of juice was measured with the help of a digital hand refractometer (PAL-1, Atago, Japan) and the results were expressed as a percentage.

Titratable acidity (TA) content obtained from the fruit juice samples was determined through neutralisation of the fruit juice with a base. For this purpose, $20 \mathrm{~mL}$ of pure water was added to $10 \mathrm{~mL}$ fruit juice and titrated with $0.1 \mathrm{~N} \mathrm{NaOH}$ until the $\mathrm{pH}$ reached 8.1, the amount of consumed $\mathrm{NaOH}$ was calculated and the TA was expressed as g malic acid $\cdot 100 \mathrm{~mL}^{-1}$ (Karacali, 2014). The $\mathrm{pH}$ value of peach juice was measured with the help of a pH metre (MP220, Mettler Toledo, Germany).

Total phenol content was determined using the Folin-Ciocalteu method. Twenty-five millilitres of methanol was added to a $5 \mathrm{~g}$ sample taken from peach fruits and this mixture was homogenised at medium speed with a homogeniser (Ultra-Turrax T18 Basic, Ika, Germany) for 2 min and then kept in dark conditions at $+4^{\circ} \mathrm{C}$ for $14-16 \mathrm{~h}$. The samples were filtered through a filter paper and kept at $-20^{\circ} \mathrm{C}$ until the analysis was done. The total phenolic content was determined by a spectrophotometer (Bio 100, Varian, Australia) by modifying the Folin-Ciocaltaeu calorimetric method (Zheng and Wang, 2001). The absorption of solutions was read at $725 \mathrm{~nm}$ wavelength in the spectrophotometer and the total phenolic content was expressed as mg of gallic acid equivalents (GAE) per $100 \mathrm{~g}$ of fresh weight $\left.(\mathrm{FW}) \cdot 100 \mathrm{~g}^{-1}\right)$.

The ferric reducing antioxidant power (FRAP) method was employed to determine the antioxidant activity (Benzie and Strain, 1996). The absorbance of the prepared solutions was read on a spectrophotometer at $593 \mathrm{~nm}$ wavelength, and the antioxidant activity values were given as $\mu \mathrm{mol}$ trolox equivalent (TE) $\cdot \mathrm{g}^{-1} \mathrm{FW}$.

\section{Statistical analysis}

Data of the experiment were analysed using the IBM $^{\circledR}$ SPSS $^{\circledR}$ Statistics 19 (IBM, NY, USA) statistical package software. Differences between the averages were determined using the Duncan test $(p \leq 0.05)$. 


\section{RESULTS AND DISCUSSION}

Average fruit weight increased with SA treatments, by $20 \%$ with $1 \mathrm{mM}$ treatment and $16 \%$ with $2 \mathrm{mM}$ treatments compared with the control. Even as the fruit width was $78.29 \mathrm{~mm}$ in the control fruits, both SA treatments achieved a 5\% increase. Simultaneously, the fruit length also increased with SA treatments (Table 1). SA treatments are known to promote cell division and expansion (Hayat et al., 2005). In the treatment of 2 and $3 \mathrm{mMSA}$ on peaches in the pre-harvest period, an increase in fruit weight and fruit width was seen throughout the study period (Ali et al., 2014). It was determined that the fruit weight and yield of peaches increased with 1 and $2 \mathrm{mM}$ SA treatments performed before harvest (Mohamadi and Pakkish, 2014). With pre-harvest SA treatment on plum trees, the fruit weight of plums of SA-treated trees was determined to be higher than those of the controls, and the main effect found for $0.5 \mathrm{mM}$ SA treatment was an increase of 25\% (Martínez-Esplá et al., 2017). In another pre-harvest SA treatment in sweet cherry, $0.5 \mathrm{mM}$ SA was the most effective dose, with the fruit weight increasing by $13 \%$ and $37 \%$, as well as fruit volume increasing by $41 \%$ and 51\% (Giménez et al., 2014). The positive effect of SA on the growth and yield may be due to its effect on plant hormones (Shakirova, 2007). In addition, it is reported that SA treatments increase the net photosynthesis rate, intrinsic $\mathrm{CO}_{2}$ concentration and water usage effectiveness (Fariduddin et al., 2003). In this study, SA applied before harvest had an increasing effect on fruit size compared with control fruits.

It is known that the fruit taste is mainly sourced from a combination of sugars and acids. TSS is an important parameter in fruit quality. The results show that TSS is not influenced by any treatment. TSS is the same in all treatments at harvest and is found to be approximately $12 \%$. There is no difference between the amount of TSS in control fruits and SA-treated fruits after shelf life (Table 2). In peaches and pineapples, the pre-harvest SA treatments showed results similar to this study, and no change in the amount of TSS occurred (Lu et al., 2011; Ali et al., 2014). In the studies that applied SA during the end of the harvest period with different species, different results have been obtained. A decrease in the amount of TSS is seen in apples and bananas that are SA treated after storage (Srivastava and Dwivedi, 2000; Mo et al., 2008), and an increase is seen in the amount of pomegranate TSS (Mirdehgnan and Ghotbi, 2014), as compared with the control. The present study shows that the SA treatments have no significant effect on TSS of peach, which may be attributed to the fact that SA behaves differently in different crops.

TA is an important quality parameter that affects taste and aroma in fruits. For this reason, it is unfavourable to decrease the acidity soon after harvest. TA content increases with SA. The results in Table 2 show that the two higher SA concentrations cause significantly higher acidity than the control at harvest and after shelf life. Untreated fruits (control) resulted in minimum TA content compared with the ones with SA concentrations at harvest and after shelf life. After shelf life, there was a decrease in TA content in all treatments, and the TA ratio of SA-treated fruits was higher in both periods than the control at harvest and after shelf life. However, there was a $21.79 \%$ decrease in $1 \mathrm{mM} \mathrm{SA}$ treatment, while a higher decrease of $13.75 \%$ in $2 \mathrm{mM}$ SA. The $2 \mathrm{mM}$ treatment also better maintained the amount of TA after shelf life (Table 2). In the pre-harvest SA treatments made in a different type of peach, the amount of TA of the fruits was found to be higher than in the control fruits

Table 1. Effect of SA treatments on fruit weight $(\mathrm{g})$, fruit width $(\mathrm{mm})$ and fruit length $(\mathrm{mm})$ values

\begin{tabular}{lccc}
\hline Applications & Fruit weight $(\mathrm{g})$ & Fruit width $(\mathrm{mm})$ & Fruit length $(\mathrm{mm})$ \\
\hline Control & $259.58 \mathrm{~b}^{* *}$ & $78.29 \mathrm{~b}^{*}$ & $79.06 \mathrm{~b}^{*}$ \\
$1 \mathrm{mM}$ & $311.83 \mathrm{a}$ & $82.26 \mathrm{a}$ & $82.86 \mathrm{ab}$ \\
$2 \mathrm{mM}$ & $300.00 \mathrm{a}$ & $82.62 \mathrm{a}$ & $83.55 \mathrm{a}$ \\
\hline
\end{tabular}

Lettering is done according to the SPPSS program. Differences between the averages were determined using the Duncan test $(p \leq 0.05)$.

**** significant at $p \leq 0.05$ and $p \leq 0.01$, respectively.

SA, salicylic acid.

Table 2. Effect of SA treatments on TSS, TA content and $\mathrm{pH}$ value at harvest and after storage plus 2-day shelf life

\begin{tabular}{|c|c|c|c|c|c|c|}
\hline \multirow[t]{2}{*}{ Application } & \multicolumn{2}{|c|}{ TSS (\%) } & \multicolumn{2}{|c|}{ TA (g malic acid $\cdot 100 \mathrm{~mL}^{-1}$ ) } & \multicolumn{2}{|c|}{$\mathrm{pH}$} \\
\hline & Harvest & Shelf life & Harvest & Shelf life & Harvest & Shelf life \\
\hline Control & $11.80 \mathrm{~ns}$ & $12.46 \mathrm{~ns}$ & $0.65 \mathrm{~b}^{\mathrm{z} *}$ & $0.55 \mathrm{~b}^{*}$ & $4.26 \mathrm{~ns}$ & $4.49 \mathrm{~ns}$ \\
\hline $1 \mathrm{mM} \mathrm{SA}$ & 12.00 & 12.56 & $0.78 \mathrm{a}$ & $0.61 \mathrm{ab}$ & 4.25 & 4.42 \\
\hline 2 mM SA & 12.00 & 12.86 & $0.80 \mathrm{a}$ & $0.69 \mathrm{a}$ & 4.25 & 4.29 \\
\hline
\end{tabular}

Lettering is done according to the SPPSS program.

${ }^{z}$ differences between averages in each column were determined by the Duncan test according to $p \leq 0.05$.

ns, ${ }^{*}$ non-significant and significant at $p \leq 0.05$, respectively.

SA, salicylic acid; TSS, total soluble solid; TA, titratable acidity. 
(Ali et al., 2014). In the pre-harvest SA treatments in plums, TA was significantly higher in the treated trees than in the controls (Martínez-Esplá et al., 2017). With the application of SA in peaches and nectarines, at the end of the harvest period, SA retained a higher content of TA during the entire storage period (Tareen et al., 2012; Hajilou and Fakhimrezaei, 2013). Pre- or/and post-harvest SA treatments in pineapple had higher TA content than the control. Moreover, a study on the pineapple demonstrated the beneficial effect of SA on fruit quality through pre-harvest spray and/or postharvest immersion (Lu et al., 2011). After the harvest of pomegranates, with SA treatment, the TA was found to be higher only in $1.4 \mathrm{mM} \mathrm{SA}$-administered pomegranates (Sayyari et al., 2009). In apples, with SA treatments after harvest, it was determined that the amount of TA was high (Shirzadeh and Kazemi, 2012). In this study, the reason that the TA content of untreated fruits of peach was low compared with those with SA treatment could be because, as stated in Ali et al. (2014), the consumption of organic acid due to the higher photosynthesis rate of untreated fruits reduced the amount of TA in fruits.

In this study, the $\mathrm{pH}$ value of the juice of peaches was determined to be approximately 4.23 (Table 2). At the time of harvest and end of shelf life, no difference was seen. Post-harvest SA treatments of $2 \mathrm{mM}$ in peaches increased the $\mathrm{pH}$ in fruit juice (Tareen et al., 2012).

Fruit colour of peach is one of the most important attributes related to fruit quality, together with TSS, TA and flesh firmness. Changes in the skin colour of peach were monitored by measuring $L^{*}, a^{*}$ and $b^{*}$ values. After harvest and storage, as well as shelf life, the effect of
SA treatments on the fruit skin colour values of peaches ( $L^{*}, a^{*}$ and $b^{*}$ ) was found to be insignificant (Table 3 ).

Fruit flesh colour changed after storage and shelf life. The effect of SA treatments on the $L^{*}$ and $a^{*}$ values of the peaches, after storage plus shelf life, was found to be significant ( $p \leq 0.05$ ), even though it was found to be insignificant at harvest time. The effect of SA treatments on the $b^{*}$ value of the peaches was found to be significant at harvest time (Table 4).

In this study, SA treatments generally affected the fruit flesh colour of peaches. A higher luminosity $\left(L^{*}\right)$ and lower $a^{*}$ (redness or anthocyanin) and $b^{*}$ (yellow colour) values were recorded in fruits treated with especially $2 \mathrm{mM}$ SA as compared with the control. In control fruits, the least $L^{*}$ and the highest $a^{*}$ and $b^{*}$ values were determined (Tables 3 and 4). The results of the study were found to be consistent with the colour values of SA treatments in peaches and strawberries (Shafiee et al., 2010; Tareen et al., 2012).

In addition to harvest and storage, the effect of preharvest SA treatments in different concentrations on the total amount of phenol content of 'Cresthaven' peach varieties was found to be significant ( $p \leq 0.05$ ) after shelf life. The total phenol content in peaches with $1 \mathrm{mM} \mathrm{SA}$ was found to be the highest after harvest at $80.17 \mathrm{mg}$ GAE $\cdot 100 \mathrm{~g}^{-1} \mathrm{FW}$, and the lowest was in the control at $65.25 \mathrm{mg} \mathrm{GAE} \cdot 100 \mathrm{~g}^{-1} \mathrm{FW}$. At the end of storage and shelf life $(8+2$ days), the total phenol content was found to be higher in peach fruits with 1 and $2 \mathrm{mM} \mathrm{SA}$ and was determined to be 84.34 and $89.06 \mathrm{mg}$ GAE $\cdot 100 \mathrm{~g}^{-1} \mathrm{FW}$, respectively (Table 5). A slight increase in the total phenol content was observed at the end of the storage period compared with the beginning.

Table 3. Effect of pre-harvest SA treatments on the fruit skin $L^{*}, a^{*}$ and $b^{*}$ values of peach fruits at harvest and after storage plus 2-day shelf life

\begin{tabular}{|c|c|c|c|c|c|c|}
\hline \multirow[t]{2}{*}{ Applications } & \multicolumn{2}{|c|}{$L^{*}$ value } & \multicolumn{2}{|c|}{$a^{*}$ value } & \multicolumn{2}{|c|}{$b^{*}$ value } \\
\hline & Harvest & Shelf life & Harvest & Shelf life & Harvest & Shelf life \\
\hline Control & $63.76 \mathrm{~ns}$ & $64.20 \mathrm{~ns}$ & $20.32 \mathrm{~ns}$ & $27.88 \mathrm{~ns}$ & $44.10 \mathrm{~ns}$ & $46.03 \mathrm{~ns}$ \\
\hline $1 \mathrm{mM} \mathrm{SA}$ & 57.24 & 58.65 & 18.41 & 25.01 & 39.49 & 41.84 \\
\hline $2 \mathrm{mM}$ SA & 57.96 & 59.02 & 17.23 & 24.45 & 36.76 & 39.90 \\
\hline
\end{tabular}

ns, non-significant.

SA, salicylic acid.

Table 4. Effect of pre-harvest SA treatments on the fruit $L^{*}, a^{*}$ and $b^{*}$ values of peach fruits at harvest and after storage plus 2-day shelf life $20^{\circ} \mathrm{C}$

\begin{tabular}{|c|c|c|c|c|c|c|}
\hline \multirow[t]{2}{*}{ Applications } & \multicolumn{2}{|c|}{$L^{*}$ value } & \multicolumn{2}{|c|}{$a^{*}$ value } & \multicolumn{2}{|c|}{$b^{*}$ value } \\
\hline & Harvest & Shelf life & Harvest & Shelf life & Harvest & Shelf life \\
\hline Control & $74.43 \mathrm{~ns}$ & $64.58 \mathrm{c}^{\mathrm{z}, *}$ & $1.42 \mathrm{~ns}$ & $7.54 \mathrm{a}^{*}$ & $64.94 \mathrm{a}^{*}$ & $61.57 \mathrm{~ns}$ \\
\hline $1 \mathrm{mM} \mathrm{SA}$ & 71.88 & $69.23 \mathrm{~b}$ & -0.28 & $4.93 \mathrm{~b}$ & $63.26 \mathrm{ab}$ & 61.36 \\
\hline $2 \mathrm{mM}$ SA & 74.62 & $72.26 \mathrm{a}$ & -0.46 & $3.81 \mathrm{~b}$ & $61.95 \mathrm{~b}$ & 58.63 \\
\hline
\end{tabular}

Lettering is done according to the SPPSS program.

${ }^{z}$ differences between averages in each column were determined by the Duncan test according to $p \leq 0.05$.

$\mathrm{ns},{ }^{*}$ non-significant and significant at $p \leq 0.05$, respectively.

SA, salicylic acid. 
Pre-harvest SA treatments were applied to sweet cherries (Giménez et al., 2014), and the total phenol increased compared with the control. In post-harvest SA treatments in peach, the total phenolic content was determined to be the highest in fruits treated with $2.0 \mathrm{mM}$ SA, which was followed by $1.5 \mathrm{mM} \mathrm{SA}$ as compared with the control (Tareen et al., 2012), and the highest amount of total phenolic content was seen in fruits treated with SA at a higher concentrations of 2 and $4 \mathrm{mM}$ than in the controls (Khademi and Ershadi, 2013). In a study on nectarine fruits, the total polyphenol compounds were $81.5 \mathrm{mg} \mathrm{GAE} \cdot 100 \mathrm{~g}^{-1} \mathrm{FW}$ at harvest time, and the treated fruits showed a significantly higher phenolic content compared with the control fruits at the end of the storage (Bal, 2016). 'Cara cara' navel oranges that were treated with SA exhibited increased total phenolic content, and a higher SA concentration was seen to have a more profound influence in this regard (Huang et al., 2008).

The effect of SA treatments on the antioxidant activity of peach fruits was significant at harvest time $(p \leq 0.05)$ and after shelf life $(p \leq 0.01)$. SA treatments increased antioxidant activity compared with the control in both periods. In peaches treated with SA, the antioxidant activity at harvest time and after shelf life was found to be high compared with the control. At the end of storage and shelf life $(8+2$ days $)$, the antioxidant activity in peaches treated with 1 and $2 \mathrm{mM}$ SA was detected to be $12.37 \mu \mathrm{mol} \mathrm{TE} \cdot \mathrm{g}^{-1} \mathrm{FW}$ and $14.30 \mu \mathrm{mol}$ $\mathrm{TE} \cdot \mathrm{g}^{-1} \mathrm{FW}$, respectively, as compared with $9.65 \mu \mathrm{mol}$ $\mathrm{TE} \cdot \mathrm{g}^{-1} \mathrm{FW}$ in the controls (Table 5). Compared with the start, a rise in the antioxidant activity of peach fruits was observed at the end of storage.

Post-harvest treatment with SA significantly enhanced the antioxidant capacity of peaches as compared with the control fruits. Similarly, SA increased the antioxidant capacity of peaches at concentrations of 1, 2 and $4 \mathrm{mM}$ (Khademi and Ershadi, 2013). Another treatment in the post-harvest period showed that $2 \mathrm{mM}$ of SA could increase the TAA of strawberry (Asghari and Aghdam, 2010). In the pre-harvest SA treatments in sweet cherry and plum, there was an increase in the antioxidant capacity compared with the control (Giménez et al., 2014; Martínez-Esplá et al., 2017).

For the estimation of harvest time and fresh market selling, fruit flesh firmness is a significant property. Significant differences were observed in the fruit flesh firmness of fruits. SA treatments preserved the flesh firmness of peaches.

It was shown that treatment with SA at harvest time was effective on fruit flesh firmness. The firmness of the SA-treated harvested fruits was higher compared with the control fruits. The decrease in firmness of the treated peach fruits after shelf life was less than that in the control fruits (Figure 1). The highest fruit flesh firmness

Table 5. Effect of different concentrations of SA treatments before harvest and storage of the total phenolic content and antioxidant activity in the 'Cresthaven' peach varieties

\begin{tabular}{|c|c|c|c|c|}
\hline \multirow[t]{2}{*}{ Applications } & \multicolumn{2}{|c|}{ Total phenol content $\left(\mathrm{mg} \mathrm{GAE} \cdot 100 \mathrm{~g}^{-1} \mathrm{FW}\right)$} & \multicolumn{2}{|c|}{ Antioxidant activity $\left(\mu \mathrm{mol} \mathrm{TE} \cdot \mathrm{g}^{-1} \mathrm{FW}\right)$} \\
\hline & Harvest & Shelf life & Harvest & Shelf life \\
\hline Control & $65.25 b^{z, *}$ & $71.61 b^{*}$ & $8.98 b^{*}$ & $9.65 b^{* *}$ \\
\hline $1 \mathrm{mM}$ SA & $80.17 \mathrm{a}$ & $84.34 \mathrm{a}$ & $11.96 \mathrm{a}$ & $12.37 \mathrm{a}$ \\
\hline $2 \mathrm{mM}$ SA & $75.91 \mathrm{ab}$ & $89.06 \mathrm{a}$ & $11.37 \mathrm{a}$ & $14.30 \mathrm{a}$ \\
\hline
\end{tabular}

Lettering is done according to the SPPSS program.

${ }^{z}$ differences between averages in each column were determined by the Duncan test according to $p \leq 0.05$.

*** significant at $p \leq 0.05$ or $p \leq 0.01$, respectively.

SA, salicylic acid; GAE, gallic acid equivalents; FW, fresh weight.

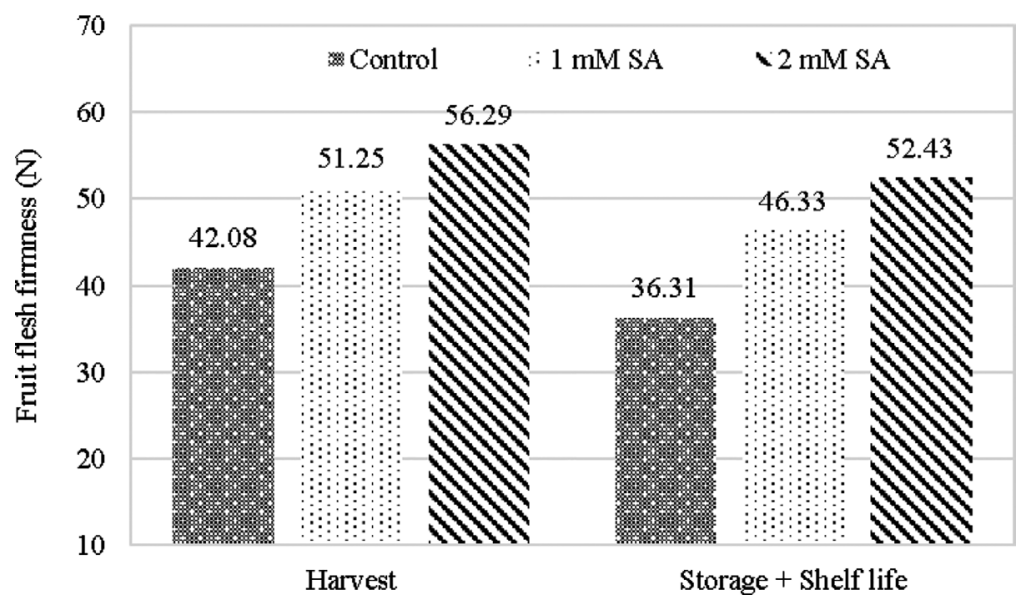

Figure 1. Effects of pre-harvest SA treatments on the fruit firmness of peach fruits at harvest and after storage plus 2-day shelf life. 
in SA treatments was obtained by utilising the $2 \mathrm{mM}$ SA treatment, while the firmness value of the $1 \mathrm{mM} \mathrm{SA}$ treated fruits was $36.31 \mathrm{~N}$ after shelf life. The controls and $1 \mathrm{mM} \mathrm{SA}$-treated fruits showed a very rapid decrease in firmness after shelf life compared with what it was in the beginning. SA, especially at $2 \mathrm{mM}$, displayed a positive effect on fruit flesh firmness. Simultaneous with the results of this study, SA treatments on peaches and plums in the pre-harvest period were reported to increase the firmness (Ali et al., 2014; Martínez-Esplá et al., 2017). The treatment by SA on peaches in the post-harvest period after storage helped to maintain greater firmness (Tareen et al., 2012; Khademi and Ershadi, 2013; Rehab, 2013; Bal, 2016). According to Wang et al. (2006) and Davarynejad et al. (2015), SA prevents fruit softening. They found that the rapid softening of fruits during ripening occurred simultaneously with a rapid decrease in the endogenous SA of fruits. SA treatment prevented softening by suppressing ethylene biosynthesis, thus delaying the climacteric rise in ethylene (Zhang et al., 2003). The results revealed that only $1 \mathrm{mM}$ SA ensured significantly higher firmness (Wang et al., 2006).

\section{CONCLUSION}

The general results revealed that pre-harvest treatments with SA enhanced some quality characteristics, such as fruit firmness, fruit weight, total phenolic content and antioxidant activity of peach fruits, at the commercial harvest time. The mentioned treatments did not display any effect on soluble solids at the harvest time, even though spraying these chemicals was found to be effective in keeping a higher amount of TA.

Total phenol content and antioxidant activity in treated trees were found to be higher after shelf life than that found in the controls. Moreover, decrease in colour change, softening and acidity was observed at lower rates in the treated peaches during storage than in the control peaches, which could be attributed to the influence of SA treatments that postponed and helped in the decline of ethylene production during storage.

In addition, the $2 \mathrm{mM}$ SA treatment has led to higher fruit firmness and less TA loss at the end of shelf life. SA-applied fruits have a higher $L^{*}$ value and lower $a^{*}$ and $b^{*}$ values. Among the treated doses (1 and $2 \mathrm{mM}$ ), the highest effects were observed when $2 \mathrm{mM}$ SA was used for the 'Cresthaven' peach cultivar.

\section{FUNDING}

No financial support for the research.

\section{AUTHOR CONTRIBUTIONS}

D.E. designed experiment. D.E. and İ.Ö carried out the field experiment. D.E. performed the laboratory analysis, data analysis and wrote the paper.

\section{CONFLICT OF INTEREST}

The authors declare no conflict of interest.

\section{REFERENCES}

Alí., Abbasi, N. A., And Hafiz I. A. (2014). Physiological Response and quality attributes of peach fruit cv. Florida king as affected by different treatments of calcium chloride, putrescine and salicylic acid. Pakistan Journal of Agricultural Sciences, 51(1), 33-39.

Asghari, M., And Aghdam, M. (2010). Impact of salicylic acid on postharvest physiology of horticultural crops. Trends in Food Science and Technology, 21, 502-509.

BAL, E. (2016). Combined treatment of modified atmosphere packaging and salicylic acid improves postharvest quality of nectarine (Prunus persica L.). Journal of Agricultural Science and Technology, 18, 1345-1354.

Baxber, G. J., Graham, A. B., Lawrence, J. R., Wile, D., And Paterson, J. R. (2001). Salicylic acid in soups prepared from organically and nonorganically grown vegetables. European Journal of Nutrition, 40, 289-292.

Babalar, M., Asghari, M., Talaei, A., And Khosroshahi, A. (2007). Effect of pre and post harvest salicylic acid treatment on ethylene production, fungal decay and overall quality of Selva strawberry fruit. Food Chemistry, 105, 449-453.

Benzie, I., and Strain, J. (1996). The ferric reducing ability of plasma (FRAP) as a measure of "Antioxidant Power: The FRAP Assay". Analytical and Bioanalytical Chemistry, 239, 70-76.

Davarynejad, G. H., Zarei, M., Nasrabadi, M. E., AND ARdaKANi, E. (2015). Effects of salicylic acid and putrescine on storability, quality attributes and antioxidant activity of plum cv. 'Santa Rosa'. Journal of Food Science and Technology, 52(4), 2053-2062.

Ding, C. K., Wang, C. Y., Gross, K. C., and Smith, D. L. (2001). Reduction of chilling injury and transcript accumulation of heat shock proteins in tomato fruit by methyl jasmonate and methyl salicylate. Plant Science, 161, 1153-1159.

Ding, C. K., And Wang, C. Y. (2003). The dual effects of methyl salicylate on ripening and expression of ethylene biosynthetic genes in tomato fruit. Plant Science, 164, 589-596.

Fariduddin, Q., Hayat, S., AND Ahmad, A. (2003). Salicylic acid influences net photosynthetic rate, carboxylation efficiency, nitrate reductase activity and seed yield in Brassica juncea. Photosynthetica, 41, 281-284.

Giménez,J.M., Valverde,J.M., Valverdo,M.J., Valero,D., Guillén, F., Martínez-Romero, D., Serrano, M., And Castílo S. (2014). Quality and antioxidant properties on sweet cherries as affected by preharvest salicylic and acetylsalicylic acids treatments. Food Chemistry, 160, 226-232.

Hajilou, J., AND FAKhimRezaei, S. (2013). Effects of postharvest calcium chloride or salicylic acid treatments on the shelf-life and quality of apricot fruit. Journal 
of Horticultural Science and Biotechnology, 88(5), 600-604.

Hayat, S., Fariduddin, Q., Ali B., And Ahmad, A. (2005). Effect of salicylic acid on growth and enzyme activities of wheat seedlings. Acta Agronomica Hungarica, 53, 433-437.

Haya,T Q., Hayat, S., Irfan, M., And Ahmad, A. (2010). Effect of exogenous salicylic acid under changing environment: A review. Environmental and Experimental Botany, 68, 14-25.

Huang, Y., Deverall, B. J., Tang, W. H., Wang, W., And WU, F. W. (2000). Foliar application of asilbenzolarS-methyl and protection of postharvest rock melons and Hami melons from disease. European Journal of Plant Pathology, 106, 651-656.

Huang, R., Xia, R., Lu, Y., Hu, L., and Xu, Y. (2008). Effect of preharvest salicylic acid spray treatment on post-harvest antioxidant in the pulp and peel of 'Cara cara' navel orange (Citrus sinenisis L. Osbeck). Journal of the Science of Food and Agriculture, 88, 229-236.

Karacali, I. (2014). Storage and marketing of horticultural products. İzmir, Turkey: Ege University Agricultural Faculty Publication, No: 494.

Khademi, Z., And Ershadi A. (2013). Postharvest application of salicylic acid improves storability of peach (Prunus persica cv. Elberta) fruits. International Journal of Agriculture and Crop Sciences, 5(6), 651-655.

Lu, X., Sun, D., Li, Y., Shi, W., And Sun, G. (2011). Pre- and post-harvest salicylic acid treatments alleviate internal browning and maintain quality of winter pineapple fruit. Scientia Horticulturae, 130, 97-101.

Martínez-Esplá, A., Zapata, P. J., Valero, D., Martínez-Romero, D., Diaz-Mulab, H. M., And Serranoc, M. (2017). Preharvest treatments with salicylates enhance nutrient and antioxidant compounds in plum at harvest and after storage. Journal of the Science of Food and Agriculture, 98, 2742-2750.

Mirdehghan, S. H., and Ghotbi F. (2014). Effects of salicylic acid, jasmonic acid, and calcium chloride on reducing chilling injury of pomegranate (Punica granatum L.). Journal of Agricultural Science and Technology, 16, 163-173.

Mo, Y., Gong, D., Liang, G., Han, R., Xiel, J., And Lil, W. (2008). Enhanced preservation effects of sugar apple fruits by salicylic acid treatment during postharvest storage. Journal of the Science of Food and Agriculture, 88, 2693-2699.

Mohamadi, H., And PAKkish, Z. (2014). Role of salicylic acid on yield improvement of 'Elberta' Peach (Prunus persica L. Batsch) tree. International Journal of Advanced Biological and Biomedical Research, 2(4), 970-973.
Rehab, M. A. (2013). Effect of post-harvest salicylic acid treatments on fruit quality of peach cv. "Flordaprince" during cold storage. Australian Journal of Basic and Applied Sciences, 7(7), 920-927.

Sayyari, M., Babalar, M., Kalantari, S., Serrano, M., AND Valero, D. 2009. Effect of salicylic acid treatment on reducing chilling injury in stored pomegranates. Postharvest Biology and Technology, $53,152-154$.

Shafiee, M., Taghavi, T. S., and Babalar, M. (2010). Addition of salicylic acid to nutrient solution combined with postharvest treatments (hot water, salicylic acid, and calcium dipping) improved postharvest fruit quality of strawberry. Scientia Hortıculturae, 124, 40-45.

ShakiRova, F. M. (2007). Role of hormonal system in the manisfestation of growth promoting and anti-stress action of salicylic acid. In S. Hayat and A. Ahmad (Eds), Salicylic acid. A plant hormone. Dordrecht, Netherlands: Springer.

Shirzadeh, E., And Kazemi, M. (2012). Effect of salicylic acid and essential oils treatments on quality characteristics of apple (Malus domestica var. Granny Smith) fruits during storage. Asian Journal of Chemistry, 7(3), 165-170.

Srivastava, M. K., and Dwivedi, U. (2000). Delayed ripening of banana fruit by salicylic acid. Plant Science, 158(1), 87-96.

Tareen, J. M., Abbasi, N. A., And Hafiz, I. A. (2012). Effect of salicylic acid treatments on storage life of peach fruits cv. 'Flordaking'. Pakistan Journal of Botany, 44(1), 119-124.

Wang, L. J., Chen, S. J., Kong, W. F., Li, S. H., And Archbold, D. D. (2006). Salicylic acid pretreatment alleviates chilling injury and effects the anti-oxidant system and heat shock proteins of peaches during cold storage. Postharvest Biology and Technology, 41, 244-251.

Xu, W. P., Chen, K. S., Li F., And Zhang, S. L. (2000). Regulation of lipoxygenase on jasmonic acid biosynthesis in ripening kiwifruit. Acta Petrologica Sinica, 26, 507-514.

YAnG, Y. N., Qi, M., And MeI, C. S. (2004). Endogenous salicylic acid protects rice plants from oxidative damage caused by aging as well as biotic and abiotic stress. The Plant Journal, 40, 909-919.

Zhang, Y., Chen, K., Zhang, S., and Ferguson, I. (2003). The role of salicylic acid in postharvest ripening of kiwifruit. Postharvest Biology and Technology, 28(1), 67-74.

Zheng, W., AND Wang, S. Y. (2001). Antioxidant activity and phenolic compounds in selected herbs. Journal of Agricultural and Food Chemistry, 49(11), 5165-5170.

Received July 06, 2020; accepted September 03, 2020. 